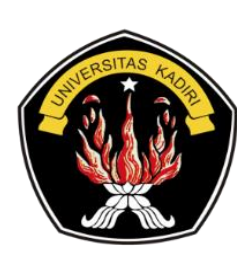

Tersedia secara online di http://ojs.unik-kediri.ac.id/index.php/jatiunik/issue/view/76

\title{
Analisis Bahaya Dengan Metode Hazard Identification, Risk Assessment And Risk Control (HIRARC) Di Lingkungan Sekolah Dalam Upaya Pencegahan Penyebaran Dan Penularan Covid-19
}

\section{Leyla Nurlita Fardiah ${ }^{* 1}$, Bayu Santoso², Haqi Fauzan Ahmad ${ }^{3}$, Fakhri Mauladiansyah ${ }^{4}$, Ghilman Baihaqi ${ }^{5}$, Zidan Ziaul Islam ${ }^{6}$, Salafudin ${ }^{7}$}

\begin{tabular}{|c|}
\hline InformasiArtikel \\
\hline Riwayat Artikel : \\
\hline $\begin{array}{l}\text { Received : } 25-\text { Juli }-2020 \\
\text { Revised : } 9-\text { Oktober }-2020 \\
\text { Accepted : } 13-\text { Oktober }-2020\end{array}$ \\
\hline
\end{tabular}

Kata kunci :

Covid-19

HIRARC

School

\section{A b s tract}

Right now the world is facing the Covid-19 outbreak virus, not least in Indonesia. This outbreak has been a pandemic since its inception at the end of 2019. The whole world is struggling to fight this pandemic, as well as in Indonesia where every struggle is increasing so much. All public places are temporarily closed to prevent the spread of the Covid-19 virus. The school became one of the public places that was temporarily closed in order to prevent the spread of the Covid-19 virus in the school environment. There are many causes for the transmission of the Covid-19 virus and the losses that can result from the Covid-19 virus. Therefore the purpose of this study is to be able to use hazards, risks and risk control using the Danger Identification, Risk Assessment and Risk Control (HIRARC) methods in the school environment. Risk identification is done by descriptive research methods, namely the results of research data and related journals available. The results of the study can be known about the activities that exist in the school environment that are needed for distribution and transmission of the Covid-19 virus. There are 14 main activities with 34 potential hazards, expected 13 activities with a high risk category and 1 activity with a high risk category. To be able to control the danger, use protection, wear a mask, always wash your hands using soap and running water and always be ready for hand sanitizer.

\section{A b s t r a k}

Saat ini dunia sedang dihadapkan dengan wabah virus Covid-19, tak terkecuali di Indonesia. Wabah tersebut sudah menjadi pandemi sejak awal kemunculannya di akhir tahun 2019. Seluruh dunia sedang berjuang untuk melawan pandemi tersebut, begitu juga di Indonesia yang setiap harinya mengalami kenaikan yang begitu besar. Semua tempat umum di tutup untuk sementara untuk mencegah penyebaran virus Covid-19. Sekolah menjadi salah satu tempat umum yang ditutup untuk sementara guna untuk mencegah penyebaran virus Covid-19 di lingkungan sekolah. Terdapat banyak sekali penyebab penularan virus covid
Untuk melakukan sitasi pada penelitian ini dengan format : Yardi, and T. Edwin, "Analisis penerapan recordable incident rate dalam sistem manajemen kesehatan dan keselamatan kerja di pt semen padang," J. Kesehat. Masy. Andala, pp. 3-9, 2019 
dan kerugian yang didapat dari virus Covid-19. Karena tujuan dari penelitian ini untuk dapat mengidentifikasi bahaya, penilaian risiko dan pengendalian risiko dengan menggunakan metode Hazard Identification, Risk Assessment and Risk Control (HIRARC) di lingkungan sekolah. Identifikasi risiko dilaksanakan dengan metode penelitian deskriptif yaitu hasil riset data dan jurnal-jurnal terkait yang tersedia. Hasil penelitian dapat diketahui bahwa terdapat kegiatan-kegiatan yang terdapat di lingkungan sekolah yang berpotensi untuk terjadinya penyebaran dan penularan virus Covid-19. Terdapat 14 kegiatan utama dengan 34 potensi bahaya, diantaranya 13 kegiatan dengan kategori risiko ekstrim dan 1 kegiatan dengan kategori risiko tinggi. Untuk dapat mengendalikan bahaya terdapat beberapa alternatif diantaranya melakukan kegiatan belajar mengajar secara online dan mematuhi seluruh protokol kesehatan seperti menjaga jarak (Physical Distancing dan Sosial Distancing), menggunakan masker, selalu mencuci tangan menggunakan sabun dan air mengalir juga selalu membawa hand sanitizer.

\section{Pendahuluan}

COVID-19 merupakan penyakit menular yang disebabkan oleh sindrom pernapasan akut coronavirus 2 (severe acute respirator syndrome coronavirus 2 atau SARS-CoV-2). Virus ini merupakan keluarga besar Corona virus yang dapat menyerang hewan. Ketika menyerang manusia, Corona virus biasanya menyebabkan penyakit infeksi saluran pernafasan, seperti flu, MERS (Middle East Respiratory Syndrome), dan SARS (Severe Acute Respiratory Syndrome) [1], [2]. COVID-19 sendiri merupakan corona virus jenis baru yang ditemukan di Wuhan, Hubei, China pada tahun 2019. Karena itu, Corona virus jenis baru ini diberi nama Corona virus disease-2019 yang disingkat menjadi COVID-19 [3]. COVID-19 sejak ditemukan menyebar secara luas hingga mengakibatkan pandemi global yang berlangsung sampai saat ini. Gejala COVID-19 umumnya berupa demam $38^{\circ} \mathrm{C}$, batuk kering, dan sesak nafas serta dampak paling buruk untuk manusia ialah kematian [4]. Sampai 19 April 2020 pukul 10:38:37 WIB, dilaporkan terdapat 2.329.539 kasus terkonfirmasi dari 185 negara yang 160.717 orang diantaranya meninggal dunia serta 595.229 orang bisa disembuhkan [5], [6].

Pandemi global yang terjadi pula di Indonesia membuat banyak pihak berupaya ikut berperan serta dalam mengatasi. Para dokter umum dan spesialis angkat bicara bersama guna memberi penjelasan singkat kepada masyarakat maupun imbauan agar menjaga kebersihan diri dan lingkungan sekaligus tak banyak keluar rumah [7]. Salah satu dampak pandemi Corona virus 2019-20 ialah terhadap pendidikan di seluruh dunia, yang mengarah kepada penutupan luas sekolah, madrasah, universitas, dan pondok pesantren. Kami turut merasakan dampak tersebut berupa perubahan pelaksanaan pembelajaran di madrasah dan pondok pesantren. Rekan kami, Surotul Ilmiah, yang sedang mengambil studi doktoral di Xiangya School of Public Health, Central South University (CSU), Changsha, Hunan, China, sampai saat ini belum bisa kembali ke universitas. UNESCO (United Nations Educational, Scientific and Cultural Organization) pada 4 Maret 2020 menyarankan penggunaan pembelajaran jarak jauh dan membuka platform pendidikan yang dapat digunakan sekolah dan guru untuk menjangkau peserta didik dari jarak jauh dan 
membatasi gangguan pendidikan [8]. Sehubungan dengan perkembangan tersebut, Kementerian Pendidikan dan Kebudayaan (Kemendikbud) turut mengambil kebijakan sebagai panduan dalam menghadapi penyakit tersebut di tingkat satuan pendidikan. Secara global, hasil pantauan UNESCO menyebutkan bahwa sampai 13 April sebanyak 191 negara telah menerapkan penutupan nasional yang berdampak kepada 1.575.270.054 siswa $(91.3 \%$ dari populasi siswa dunia) [9], [10].

Penelitian ini bertujuan untuk mengetahui potensi bahaya, risiko bahaya yang ditimbulkan serta rekomendasi apa saja yang harus dilakukan untuk mengurangi paparan virus corona di lingkungan sekolah. Metode dalam penelitian ini menggunakan metode Hazard Identification, Risk Assessment And Risk Control (HIRARC).

\section{Tinjauan Pustaka}

\subsection{Likelyhood}

Tabel 1. Likelyhood

\begin{tabular}{|l|c|l|}
\hline \multicolumn{1}{|c|}{ Deskripsi } & Nilai & \multicolumn{1}{c|}{ Penjelasan Kualitatif } \\
\hline $\begin{array}{l}\text { Sangat Sering Terjadi } \\
\text { (Frequent) }\end{array}$ & 5 & $\begin{array}{l}\text { Dapat terjadi pada berbagai keadaan, sering } \\
\text { muncul pada waktu-waktu tertentu }\end{array}$ \\
\hline $\begin{array}{l}\text { Sering Terjadi } \\
\text { (Probabie) }\end{array}$ & 4 & $\begin{array}{l}\text { Terjadi beberapa kali dalam beberapa situasi } \\
\text { atau keadaan }\end{array}$ \\
\hline $\begin{array}{l}\text { Mungkin Terjadi } \\
\text { (Occasional) }\end{array}$ & 3 & Mungkin dapat terjadi dalam suatu keadaan \\
\hline Jarang Terjadi (Remote) & 2 & $\begin{array}{l}\text { Tidak pernah terjadi, tetapi mungkin terjadi } \\
\text { dalam beberapa situasi }\end{array}$ \\
\hline $\begin{array}{l}\text { Sangat Jarang Terjadi } \\
\text { (Improbable) }\end{array}$ & 1 & $\begin{array}{l}\text { Dapat diasumsikan tidak akan pernah terjadi } \\
\text { dalam kondisi yang luar biasa }\end{array}$ \\
\hline
\end{tabular}

Sumber : [11]-[13]

\subsection{Severity}

Tabel 2. Severity

\begin{tabular}{|c|c|l|}
\hline Kriteria & Nilai & \multicolumn{1}{|c|}{ Deskripsi } \\
\hline $\begin{array}{c}\text { Berbahaya } \\
\text { (Catastrhopic })\end{array}$ & 5 & $\begin{array}{l}\text { Peristiwa yang sangat mengancam jiwa dapat } \\
\text { menyebabkan kematian }\end{array}$ \\
\hline $\begin{array}{c}\text { Berat } \\
\text { (Major })\end{array}$ & 4 & $\begin{array}{l}\text { Cedera parah atau trauma yang } \\
\text { membutuhkan perawatan rumah sakit yang } \\
\text { mendesak }\end{array}$ \\
\hline $\begin{array}{c}\text { Sedang } \\
\text { (Serious })\end{array}$ & 2 & $\begin{array}{l}\text { Melukai cedera atau trauma yang } \\
\text { membutuhkan perawatan di rumah sakit }\end{array}$ \\
\hline $\begin{array}{c}\text { Kecil } \\
\text { (Minor })\end{array}$ & 1 & $\begin{array}{l}\text { Cidera atau trauma yang tidak terlalu } \\
\text { pengaruh tetapi membutuhkan perawatan di } \\
\text { rumah sakit }\end{array}$ \\
\hline $\begin{array}{l}\text { Tidak Signifikan } \\
\text { memerlukan perawatan di rumah sakit trauma ringan yang tidak }\end{array}$ \\
\hline
\end{tabular}

Sumber : [14]-[18] 


\subsection{Matrix Table}

Tabel 3. Matrix Table

\begin{tabular}{llllll}
\hline Likelyhood & \multicolumn{5}{c}{ Severity } \\
\cline { 2 - 6 } & $\begin{array}{l}\text { Tidak } \\
\text { Signifikan } \\
(1)\end{array}$ & Kecil (2) & $\begin{array}{l}\text { Sedang } \\
(3)\end{array}$ & Berat (4) & $\begin{array}{l}\text { Berbahaya } \\
(5)\end{array}$ \\
\hline Sangat Jarang Terjadi & 1 & 2 & 3 & 4 & 5
\end{tabular}

(1)

\begin{tabular}{llllll}
\hline Jarang Terjadi (2) & 2 & 4 & 6 & 8 & 10 \\
\hline Mungkin Terjadi (3) & 3 & 6 & 9 & 12 & 15 \\
\hline Sering Terjadi (4) & 4 & 8 & 12 & 16 & 20 \\
\hline Sangat Sering Terjadi & 5 & 10 & 15 & 20 & 25
\end{tabular}

Sumber : [16], [19]-[22]

\section{Level Risiko:}

$1-3$ : Rendah

$4-6$ : Sedang

$7-14$ : Tinggi

15 - 25: Ekstrim

\section{Metode Penelitian}

Penelitian ini adalah penelitian dekskriptif eksperimen yang dimaksudkan untuk memberikan masukan terhadap penanganan pandemi Covid-19 [23], [24]. Sumber data yang didapatkan dalam penelitian ini bersumber dari data sekunder yang terdiri dari buku, jurnal, penelitian, regulasi dan kebijakan, serta berita elektronik yang berkaitan dengan penelitian ini. Penelitian disusun menggunakan metode dekriptif analitis guna memudahkan pemahaman atas penelitian ini. Guna mencapai sebuah kesimpulan penelitian ini menggunakan metode induktif dalam proses penyusunannya. Objek penelitian yang diambil adalah kegiatankegiatan yang ada di lingkungan sekolah yaitu segala bentuk kegitatan yang berpotensi bahaya dan berisiko dalam penularan dan penyebaran virus Covid-19.

\section{Hasil dan Pembahasan}

Berdasarkan hasil pengolahan data yang sudah dilakukan mengenai identifikasi bahaya dan risiko yang terjadi akibar dari virus Covid-19, diperoleh bahwa dari 14 jenis kegiatan yang ada di lingkungan sekolah terdapat 14 kegiatan. Dapat disimpulkan bahwa kategori yang telah diidentifikasi memiliki level risiko ekstrim dan risiko tinggi. Untuk mempermudah mendapatkan hasil yang diperoleh dalam penelitian ini dapat digambarkan dalam bentuk tabel rekapitulasi menggunakan tabel HIRA. Berikut ini merupakan hasil rekapitulasi menggunakan metode HIRA :

Tabel 4. Penilaian Kegiatan Menggunakan Metode HIRA

\begin{tabular}{|c|c|c|c|c|c|c|c|c|}
\hline \multirow[t]{2}{*}{ No. } & \multirow{2}{*}{$\begin{array}{l}\text { Jenis } \\
\text { Kegiatan }\end{array}$} & Potensi Bahaya dan & \multicolumn{2}{|c|}{ Severity } & \multicolumn{2}{|c|}{ Frekuensi } & \multirow{2}{*}{$\begin{array}{l}\text { Nilai } \\
\text { Risik } \\
\text { o }\end{array}$} & \multirow{2}{*}{$\begin{array}{l}\text { Level } \\
\text { Rlisko }\end{array}$} \\
\hline & & & Kategori & $\begin{array}{c}\text { Nila } \\
\text { i }\end{array}$ & $\begin{array}{c}\text { Katego } \\
\text { ri }\end{array}$ & $\begin{array}{c}\text { Nila } \\
\text { i }\end{array}$ & & \\
\hline
\end{tabular}




\begin{tabular}{|c|c|c|c|c|c|c|c|c|}
\hline & & & & & \multicolumn{4}{|c|}{$\begin{array}{l}\text { Baha } \\
\text { ya }\end{array}$} \\
\hline 1 & $\begin{array}{c}\text { Upacara } \\
\text { bendera } \\
\text { pada hari } \\
\text { senin. }\end{array}$ & 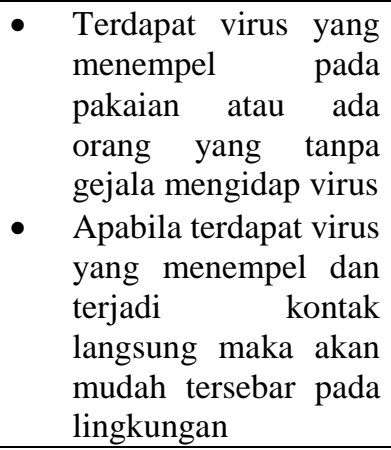 & Berbahaya & 5 & $\begin{array}{l}\text { Sangat } \\
\text { Sering } \\
\text { Terjadi }\end{array}$ & 5 & 20 & Ekstrim \\
\hline 2 & $\begin{array}{c}\text { Kegiatan } \\
\text { belajar } \\
\text { dan } \\
\text { mengajar. }\end{array}$ & 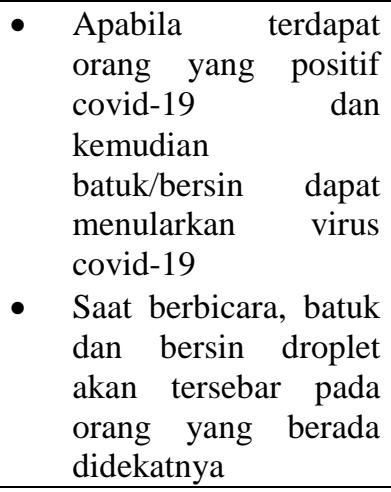 & Berbahaya & 5 & $\begin{array}{l}\text { Sangat } \\
\text { Sering } \\
\text { Terjadi }\end{array}$ & 5 & 20 & Ekstrim \\
\hline 3 & $\begin{array}{c}\text { Beribadah } \\
.\end{array}$ & $\begin{array}{lr}\text { - } & \begin{array}{l}\text { Menggunakan } \\
\text { ibadah }\end{array} \\
\text { bergantian decara } \\
\text { orang lain } \\
\text { - dengan } \\
\text { Jika terdapat orang } \\
\text { yang positif terkena } \\
\text { virus covid-19 maka } \\
\begin{array}{lr}\text { akan } & \text { terjadi } \\
\text { penyebaran yang } & \text { sangat cepat }\end{array} \\
\end{array}$ & Berat & 4 & $\begin{array}{l}\text { Sering } \\
\text { Terjadi }\end{array}$ & 4 & 16 & Ekstrim \\
\hline 4 & $\begin{array}{l}\text { Membeli } \\
\text { makanan } \\
\text { di kantin. }\end{array}$ & 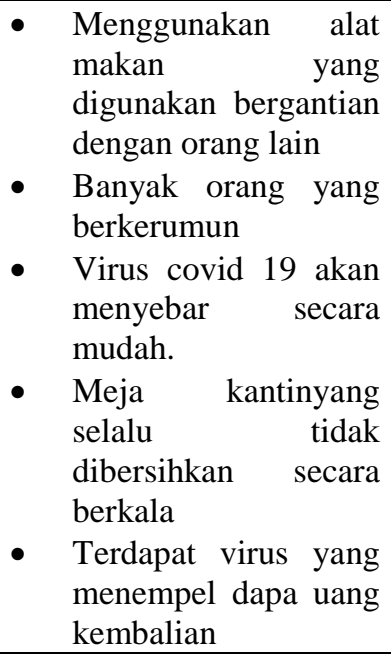 & Berbahaya & 5 & $\begin{array}{l}\text { Sangat } \\
\text { Sering } \\
\text { Terjadi }\end{array}$ & 5 & 20 & Ekstrim \\
\hline 5 & $\begin{array}{l}\text { Pengguna } \\
\text { an toilet } \\
\text { di } \\
\text { sekolah. }\end{array}$ & 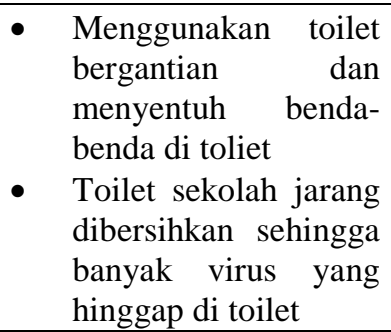 & Berbahaya & 5 & $\begin{array}{l}\text { Sangat } \\
\text { Sering } \\
\text { Terjadi }\end{array}$ & 5 & 20 & Ekstrim \\
\hline
\end{tabular}




\begin{tabular}{|c|c|c|c|c|c|c|c|c|}
\hline 6 & $\begin{array}{c}\text { Kerja } \\
\text { bakti di } \\
\text { sekolah. }\end{array}$ & \begin{tabular}{llr} 
- & \multicolumn{2}{l}{ Terkontaminasi } \\
dengan virus & saat \\
berinterksi dan & tidak \\
menjaga jarak & \\
- & $\begin{array}{l}\text { Pengunaan } \\
\text { kebersihan alat } \\
\text { bersamaan }\end{array}$ & seacra \\
\end{tabular} & Berat & 4 & $\begin{array}{l}\text { Sangat } \\
\text { Sering } \\
\text { Terjadi }\end{array}$ & 5 & 15 & Ekstrim \\
\hline 7 & $\begin{array}{l}\text { Kegiatan } \\
\text { olahraga. }\end{array}$ & 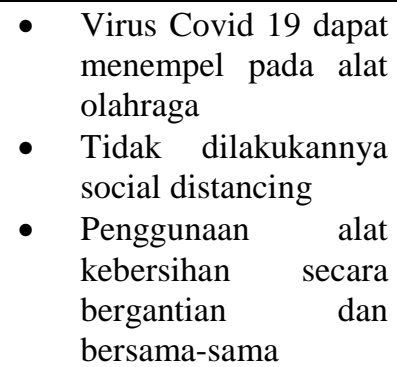 & Berat & 4 & $\begin{array}{l}\text { Sangat } \\
\text { Sering } \\
\text { Terjadi }\end{array}$ & 5 & 20 & Ekstrim \\
\hline 8 & $\begin{array}{c}\text { Kegiatan } \\
\text { ekstrakuli } \\
\text { kuler. }\end{array}$ & 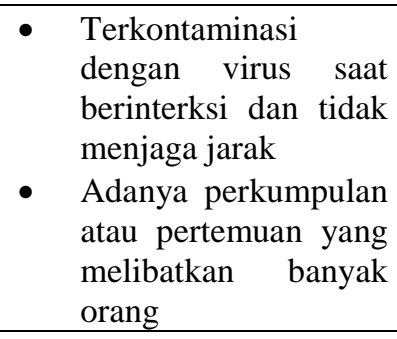 & Berat & 4 & $\begin{array}{l}\text { Sangat } \\
\text { Sering } \\
\text { Terjadi }\end{array}$ & 5 & 20 & Ekstrim \\
\hline 9 & $\begin{array}{c}\text { Kegiatan } \\
\text { evaluasi } \\
\text { belajar } \\
\text { (UTS dan } \\
\text { UAS). }\end{array}$ & $\begin{array}{l}\text { - Peminjaman alat tulis } \\
\text { dan pemakaian } \\
\text { bersama dapat } \\
\text { terinfeksi virus yang } \\
\text { terkontaminasi pada } \\
\text { benda } \\
\text { Kegiatan UTS dan } \\
\text { UAS dengan posisi } \\
\text { duduk yang } \\
\text { berdekatan }<1 \text { meter, } \\
\text { dapat terinfeksi virus } \\
\text { covid19 }\end{array}$ & Sedang & 3 & $\begin{array}{l}\text { Sering } \\
\text { Terjadi }\end{array}$ & 4 & 12 & Tinggi \\
\hline 10 & $\begin{array}{c}\text { Acara di } \\
\text { sekolah } \\
\text { internal } \\
\text { maupun } \\
\text { eksternal. }\end{array}$ & \begin{tabular}{lr}
\multicolumn{3}{l}{ Mengadakan } & acara \\
oleh OSIS & sehingga \\
banyak & siswa \\
berkumpul dalam satu \\
tempat dengan jarak \\
masing-masing & orang \\
< dari 1 meter, dapat \\
terinfeksi covid-19. \\
- Menjadi r tempat \\
paling r sering \\
berinteraksi r atau \\
bertemu satu & sama \\
lain &
\end{tabular} & Berat & 4 & $\begin{array}{l}\text { Sangat } \\
\text { Sering } \\
\text { Terjadi }\end{array}$ & 5 & 20 & Ekstrim \\
\hline 11 & $\begin{array}{c}\text { Kegiatan } \\
\text { perlomba } \\
\text { an antar } \\
\text { kelas. }\end{array}$ & $\begin{array}{l}\text { - Mengadakan berbagai } \\
\text { macam perlombaan } \\
\text { oleh OSIS sehingga } \\
\text { banyak para siswa } \\
\text { berkumpul dalam satu } \\
\text { tempat dengan jarak } \\
\text { masing-masing orang } \\
\text { < dari } 1 \text { meter, dapat } \\
\text { terinfeksi covid-19. } \\
\text { - Menyentuh benda- }\end{array}$ & Berat & 4 & $\begin{array}{l}\text { Sangat } \\
\text { Sering } \\
\text { Terjadi }\end{array}$ & 5 & 20 & Ekstrim \\
\hline
\end{tabular}




\begin{tabular}{|c|c|c|c|c|c|c|c|c|}
\hline & & $\begin{array}{lr}\text { benda } & \text { sekitar dan } \\
\text { saling } & \text { berinteraksi } \\
\text { tanpa } & \text { menjaga jarak } \\
\text { aman } & \end{array}$ & & & & & & \\
\hline 12 & $\begin{array}{c}\text { Penerima } \\
\text { an peserta } \\
\text { didik } \\
\text { baru. }\end{array}$ & 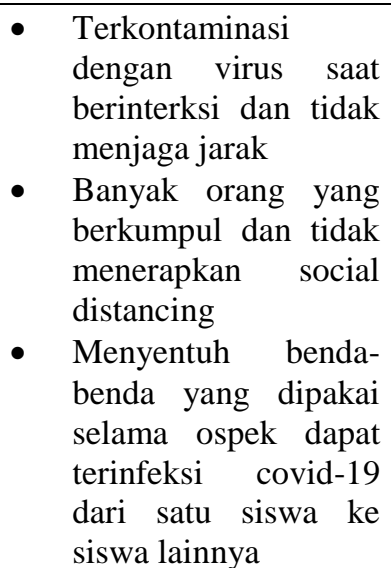 & Sedang & 3 & $\begin{array}{l}\text { Sangat } \\
\text { Sering } \\
\text { Terjadi }\end{array}$ & 5 & 15 & Ekstrim \\
\hline 13 & $\begin{array}{c}\text { Kegiatan } \\
\text { pembagia } \\
\text { n rapot di } \\
\text { setiap } \\
\text { semester. }\end{array}$ & 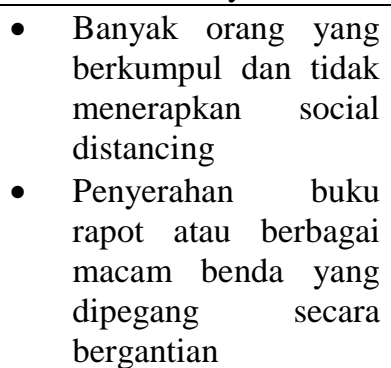 & Sedang & 3 & $\begin{array}{l}\text { Sangat } \\
\text { Sering } \\
\text { Terjadi }\end{array}$ & 5 & 15 & Ekstrim \\
\hline 14 & $\begin{array}{l}\text { Kegiatan } \\
\text { piket di } \\
\text { kelas. }\end{array}$ & $\begin{array}{l}\text { - } \begin{array}{l}\text { Terkontaminasi } \\
\text { dengan virus saat } \\
\text { berinterksi dan tidak } \\
\text { menjaga jarak }\end{array} \\
\text { - } \begin{array}{l}\text { Penggunaan alat } \\
\text { kebersihan secara }\end{array} \\
\text { bergantian } \\
\text { Didalam kelas } \\
\text { terdapat benda-benda } \\
\text { tempat virus } \\
\text { menempel dan lewat } \\
\text { udara virus telah } \\
\text { menyebar }\end{array}$ & Berat & 4 & $\begin{array}{l}\text { Sangat } \\
\text { Sering } \\
\text { Terjadi }\end{array}$ & 5 & 20 & Ekstrim \\
\hline
\end{tabular}

Tabel 5. Pengendalian Risiko

\begin{tabular}{|c|c|c|c|}
\hline No & $\begin{array}{c}\text { Jenis } \\
\text { Kegiatan }\end{array}$ & $\begin{array}{l}\text { Level } \\
\text { Risiko }\end{array}$ & Risk Control \\
\hline 1 & $\begin{array}{l}\text { Upacara } \\
\text { bendera pada } \\
\text { hari senin. }\end{array}$ & Ekstrim & $\begin{array}{l}\text { - Kegiatan upacara bendera dilakukan dirumah masing-masing } \\
\text { dengan menggunakan pakaian lengkap untuk para siswa yang } \\
\text { pelaksanaannya disiarkan langsung oleh pihak sekolah secara } \\
\text { Daring }\end{array}$ \\
\hline 2 & $\begin{array}{l}\text { Kegiatan } \\
\text { belajar dan } \\
\text { mengajar. }\end{array}$ & Ekstrim & $\begin{array}{l}\text { - } \text { Kegiatan belajar mengajar dilakukan secara Daring (Online } \\
\text { Learning System) } \\
\text { Para siswa mengumpulkan pekerjaan rumah (PR) online, } \\
\text { melalui WA orang tua, email atau media komunikasi lainnya } \\
\text { - Proses belajar mengajar dapat dilakukan dengan cara video } \\
\text { call, video conference, atau berbagai macam cara } \\
\text { pembelajaran melalui Daring } \\
\text { Para siswa menggunakan jaringan internet seperti wifi atau } \\
\text { kuota untuk dapat menunjang proses pembelajaran jarak jauh } \\
\end{array}$ \\
\hline
\end{tabular}




\begin{tabular}{|c|c|c|c|}
\hline 3 & Beribadah. & Ekstrim & $\begin{array}{ll}\text { - } & \text { Dianjurkan untuk melakukan kegiatan peribadatan di rumah } \\
\text { - } & \text { Memberi jarak aman untuk beribadah minimal } 1 \text { meter } \\
\text { - } & \text { Selalu menggunakan masker untuk menjaga dari terpaparnya } \\
\text { virus }\end{array}$ \\
\hline 4 & $\begin{array}{l}\text { Membeli } \\
\text { makanan di } \\
\text { kantin. }\end{array}$ & Ekstrim & $\begin{array}{l}\text { - } \quad \text { Para siswa membawa peralatan makan pribadi } \\
\text { - } \quad \text { Para siswa membawa bekal dari rumah yang telah di siapkan } \\
\text { sendiri. } \\
\text { - Membawa sendniri Hand sanitizer, sabun dan masker serta } \\
\text { alat kebersihan lainnya dari rumah } \\
\text { - Pihak sekolah dapat menyediakan alat kebersihan seperti hand } \\
\text { sanitizer dan tempat untuk mencuci tangan dengan air } \\
\text { mengalair di beberapa titik di kantin } \\
\text { Memberikan jarak duduk untuk makan di kantin (di selang } \\
\text { satu bangku atau > } 1 \text { meter) }\end{array}$ \\
\hline 5 & $\begin{array}{l}\text { Penggunaan } \\
\text { toilet di } \\
\text { sekolah. }\end{array}$ & Ekstrim & 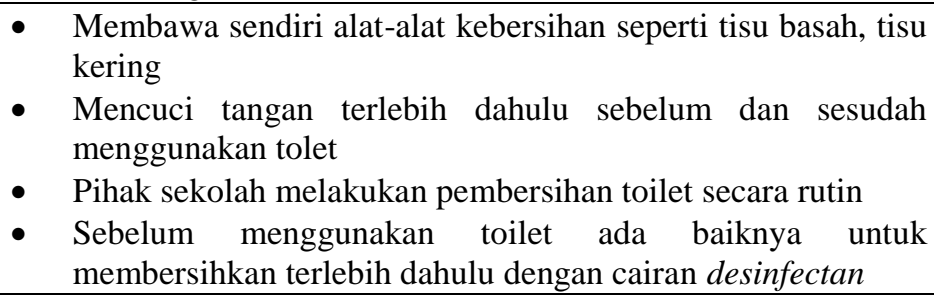 \\
\hline 6 & $\begin{array}{l}\text { Kerja bakti di } \\
\text { sekolah. }\end{array}$ & Ekstrim & $\begin{array}{l}\text { - Sekolah di tutup sementara untuk mencegah adanya penularan } \\
\text { atau penyebaran virus Covid-19 di lingkungan sekolah } \\
\text { - Tidak ada kegiatan bersih-bersih di sekolah oleh siswa, } \\
\text { kegiatan bersih-bersih dilakukan dirumah masing-masing }\end{array}$ \\
\hline 7 & $\begin{array}{l}\text { Kegiatan } \\
\text { olahraga. }\end{array}$ & Ekstrim & $\begin{array}{l}\text { - Dilakukan dengan menjaga jarak aman minimal } 1 \text { meter } \\
\text { - Selalu menggunakan hand sanitizer sebelum dan sesudah } \\
\text { menggunakan alat olahraga secara bersamaan } \\
\text { - Membawa perlengkapan olahraga sendiri seperti handuk, } \\
\text { botol minum, kaos kaki, baju ganti }\end{array}$ \\
\hline 8 & $\begin{array}{l}\text { Kegiatan } \\
\text { ekstrakulikuler. }\end{array}$ & Ekstrim & $\begin{array}{l}\text { - Jika kegiatan memungkinkan untuk dilakukan di secara } \\
\text { daring, maka dianjurkan untuk melakukan kegiatan } \\
\text { ekstrakulikuler ssecara daring } \\
\text { - Segala bentuk acara yang akan diselengarakan yang } \\
\text { melibatkan banyak orang untuk di batalkan atau di tunda } \\
\text { hingga waktu yang telah ditentukan }\end{array}$ \\
\hline 9 & $\begin{array}{l}\text { Kegiatan } \\
\text { evaluasi belajar } \\
\text { (UTS dan } \\
\text { UAS). }\end{array}$ & Tinggi & $\begin{array}{l}\text { - Ujian Tengah Semester atau Ujian Akhir Semester dilakukan } \\
\text { secara online } \\
\text { - Para siswa menggunakan internet atau kuota untuk dapat } \\
\text { mengerjakan tugas dan mengumpulkan tugas }\end{array}$ \\
\hline 10 & $\begin{array}{l}\text { Acara di } \\
\text { sekolah } \\
\text { internal } \\
\text { maupun } \\
\text { eksternal. }\end{array}$ & Ekstrim & $\begin{array}{l}\text { - Sekolah di tutup sementara untuk mencegah adanya penularan } \\
\text { atau penyebaran virus Covid-19 di lingkungan sekolah } \\
\text { - Segala bentuk acara yang akan diselengarakan yang } \\
\text { melibatkan banyak orang untuk di batalkan atau di tunda } \\
\text { hingga waktu yang telah ditentukan } \\
\text { - Jika memungkinakan kegiatan dapat dilakukan secara daring }\end{array}$ \\
\hline 11 & $\begin{array}{l}\text { Kegiatan } \\
\text { perlombaan } \\
\text { antar kelas. }\end{array}$ & Ekstrim & $\begin{array}{l}\text { - Sekolah di tutup sementara untuk mencegah adanya penularan } \\
\text { atau penyebaran virus Covid-19 di lingkungan sekolah } \\
\text { - Segala bentuk acara yang akan diselengarakan yang } \\
\text { melibatkan banyak orang untuk di batalkan atau di tunda } \\
\text { hingga waktu yang telah ditentukan }\end{array}$ \\
\hline 12 & $\begin{array}{l}\text { Penerimaan } \\
\text { peserta didik } \\
\text { baru. }\end{array}$ & Ekstrim & $\begin{array}{ll}\text { - } & \text { Pendaftaran dilakukan dengan sistem online } \\
\text { - } & \text { Pengiriman berkas-berkas di kirim secara } \text { online } \\
\text { - } & \text { Kegiatan pengesahan siswa baru melalui online } \\
\end{array}$ \\
\hline 13 & $\begin{array}{l}\text { Kegiatan } \\
\text { pembagian }\end{array}$ & Ekstrim & $\begin{array}{l}\text { - Pembagian rapot dilakukan dengan membuat beberapa sesi } \\
\text { dalam } 1 \text { hari mecegah adanya kerumunan orang } \\
\text { - Pelaksananya tetap dengan menjaga jarak aman minimal } 1 \\
\text { meter }\end{array}$ \\
\hline
\end{tabular}




\begin{tabular}{|c|c|c|c|}
\hline & $\begin{array}{l}\text { rapot di setiap } \\
\text { semester. }\end{array}$ & & $\begin{array}{l}\text { - Pihak sekolah menyediakan tempat untuk mencuci tangan } \\
\text { - Selalu menggunakan masker dan membawa hand sanitizer } \\
\text { - Selalu menggunakan masker untuk menjaga diri dari } \\
\text { terpaparnya virus }\end{array}$ \\
\hline 14 & $\begin{array}{l}\text { Kegiatan piket } \\
\text { di kelas. }\end{array}$ & Ekstrim & $\begin{array}{l}\text { - Sekolah di tutup sementara untuk mencegah adanya penularan } \\
\text { atau penyebaran virus Covid-19 di lingkungan sekolah } \\
\text { - Tidak ada kegiatan bersih-bersih di kelaas oleh siswa, } \\
\text { kegiatan bersih-bersih dilakukan dirumah masing-masing }\end{array}$ \\
\hline
\end{tabular}

\begin{tabular}{|c|c|c|c|c|c|}
\hline No & $\begin{array}{l}\text { Guide Word } \\
+ \text { Parameter }\end{array}$ & Penyebab & Konsekuensi & Safeguard & $\begin{array}{c}\text { Tindakan yang } \\
\text { Dibutuhkan }\end{array}$ \\
\hline
\end{tabular}

\begin{tabular}{|c|c|c|c|c|c|}
\hline 1 & $\begin{array}{l}\text { Tempat } \\
\text { duduk dan } \\
\text { meja di kelas }\end{array}$ & $\begin{array}{l}\text { Sering memegang } \\
\text { kursi atau meja } \\
\text { kemudian } \\
\text { memegang wajah } \\
\text { tanpa mencuci } \\
\text { tangan terlebih } \\
\text { dahulu sedangkan } \\
\text { virus dapat saja } \\
\text { menempel pada } \\
\text { kursi atau meja }\end{array}$ & $\begin{array}{l}\text { Benda tersebut } \\
\text { dapat } \\
\text { menyebabkan virus } \\
\text { menempel dan } \\
\text { dapat menularkan } \\
\text { virus pada } \\
\text { pengguna meja dan } \\
\text { kursi lain }\end{array}$ & $\begin{array}{l}\text { Alat Pelindung } \\
\text { Diri (APD) } \\
\text { seperti sarung } \\
\text { tangan, masker } \\
\text { atau face shield } \\
\text { serta membawa } \\
\text { Hand Sanitizer }\end{array}$ & \begin{tabular}{lr}
\multicolumn{2}{l}{ Menyemprotkan } \\
disinfektan pada meja \\
dan kursi, rajin mencuci \\
tangan dengan sabun \\
menggunakan & air \\
mengalir & atau \\
menggunakan & \\
handsanitizer & dan \\
menggunakan & APD \\
yang sesuai dengan & semestinya
\end{tabular} \\
\hline 2 & $\begin{array}{l}\text { Peralatan } \\
\text { menulisa dan } \\
\text { belajar } \\
\text { mengajar. }\end{array}$ & $\begin{array}{l}\text { Virus dapat } \\
\text { menepel pada alat } \\
\text { tulis tersbut yang } \\
\text { digunakan } \\
\text { bersama }\end{array}$ & $\begin{array}{lr}\text { Benda tersebut } \\
\text { dapat menyebab } \\
\text { menjadi tempat } \\
\text { virus menepel dan } \\
\text { menularkan ke } \\
\text { pengguna yang lain }\end{array}$ & $\begin{array}{l}\text { Selalu rajin } \\
\text { mencuci } \\
\text { dengan sabun } \\
\text { dan air mengalir } \\
\text { atau bisa } \\
\text { menggunakan } \\
\text { hand sanitizer }\end{array}$ & $\begin{array}{lr}\text { Selalu membersihkan } \\
\text { alat tulis } \quad \text { tersebut } \\
\text { dengan } & \text { cairan } \\
\text { desinfectan atau hand } \\
\text { sanitizer }\end{array}$ \\
\hline 3 & $\begin{array}{l}\text { Peralatan dan } \\
\text { benda-benda } \\
\text { yang berada } \\
\text { di kamar } \\
\text { mandi }\end{array}$ & $\begin{array}{lr}\text { Virus } & \text { dapat } \\
\text { menepel } & \text { pada } \\
\text { benda-benda } & \text { di } \\
\text { dalam } & \text { toilet } \\
\text { tersbut } & \text { yang } \\
\text { digunakan } & \\
\text { bersama } & \end{array}$ & $\begin{array}{lr}\text { Virus } & \text { dapat } \\
\text { menempel, } & \\
\text { menyebar dan } & \text { dada } \\
\text { menularkan } & \text { padika } \\
\text { benda } & \text { ketika } \\
\text { sedang } & \\
\text { menggunakan } & \\
\text { tiolet } & \text { dan } \\
\text { menyentuh } & \\
\text { macam-macam } \\
\text { benda tersebut } \\
\text { yang tidak } \\
\text { dibersihkan } & \text { secara } \\
\text { berkala } & \\
\end{array}$ & $\begin{array}{l}\text { Selalu rajin } \\
\text { mencuci tangan } \\
\text { dengan sabun } \\
\text { dan air mengalir } \\
\text { atau bisa } \\
\text { menggunakan } \\
\text { hand sanitizer } \\
\text { dan tidak lupa } \\
\text { selalu } \\
\text { menggunakan } \\
\text { masker }\end{array}$ & $\begin{array}{l}\text { Untuk membersihkan } \\
\text { toilet secara detail dan } \\
\text { berkala agar virus dan } \\
\text { kuman tidak bersarang } \\
\text { di toilet tersebut }\end{array}$ \\
\hline 4 & $\begin{array}{l}\text { Pegangan } \\
\text { pintu }\end{array}$ & $\begin{array}{lr}\text { Virus } & \text { dapat } \\
\text { menepel } & \text { pada } \\
\text { pegangan } & \text { pintu } \\
\text { tersbut } & \text { yang } \\
\text { digunakan } & \\
\text { bersama } & \end{array}$ & $\begin{array}{l}\text { Virus dapat } \\
\text { menempel dan } \\
\text { menyebar pada } \\
\text { pegangan atau } \\
\text { gagang pintu yang } \\
\text { jarang dibersihkan }\end{array}$ & $\begin{array}{l}\text { Alat Pelindung } \\
\text { Diri (APD) } \\
\text { seperti sarung } \\
\text { tangan, masker } \\
\text { atau face shield } \\
\text { serta membawa } \\
\text { Hand Sanitizer }\end{array}$ & $\begin{array}{l}\text { Membuka pintu dengan } \\
\text { menggunakan sikut, } \\
\text { selalu mencuci tangan } \\
\text { dengan sabun dan air } \\
\text { mengalir atau dapat } \\
\text { menggunakan hand } \\
\text { sanitizer } \\
\text { menyemprotkan } \\
\text { pegangan pintu tersebut } \\
\text { dengan cairan } \\
\text { desinfektan }\end{array}$ \\
\hline
\end{tabular}




\begin{tabular}{|c|c|c|c|c|c|}
\hline 5 & $\begin{array}{l}\text { Meja dan } \\
\text { kursi makan } \\
\text { kantin }\end{array}$ & $\begin{array}{l}\text { Memegang kursi } \\
\text { atau meja kantin, } \\
\text { memegang uang } \\
\text { kembalian lalu } \\
\text { lupa mencuci } \\
\text { tangan dengan } \\
\text { sabun dan air } \\
\text { mengalir }\end{array}$ & $\begin{array}{lr}\text { Virus } & \text { dapat } \\
\text { menempel dan } \\
\text { menyebar pada } \\
\text { meja, kursi dan } \\
\text { uang kembalian } \\
\text { yang jarang } \\
\text { dibersihkan }\end{array}$ & $\begin{array}{l}\text { Alat Pelindung } \\
\text { Diri (APD) } \\
\text { seperti sarung } \\
\text { tangan, masker } \\
\text { atau face shield } \\
\text { serta membawa } \\
\text { Hand Sanitizer }\end{array}$ & $\begin{array}{l}\text { Selalu mencuci tangan } \\
\text { dengan sabun dan air } \\
\text { mengalir } \\
\text { menyemprotkan cairan } \\
\text { desinfectan pada meja } \\
\text { dan kursi makan di } \\
\text { kantin, jangan terlalu } \\
\text { sering memegang meja } \\
\text { atau kursi makan di } \\
\text { kantin }\end{array}$ \\
\hline 6 & $\begin{array}{l}\text { Peralatan } \\
\text { makan di } \\
\text { kantin }\end{array}$ & \begin{tabular}{lr} 
Peralatan & makan \\
digunakan & secara \\
bersama & dan \\
dicuci & belum \\
\multicolumn{2}{l}{ sampai bersih }
\end{tabular} & $\begin{array}{l}\text { Dapat menularkan } \\
\text { virus karena } \\
\text { penggunaan alat } \\
\text { makan bersamaan } \\
\text { dapat membawa } \\
\text { droplet atau air lliur } \\
\text { dari suspek }\end{array}$ & $\begin{array}{l}\text { Membawa } \\
\text { peralatan makan } \\
\text { sendiri }\end{array}$ & $\begin{array}{l}\text { Selalu membersihkan } \\
\text { ulang peralatan makan } \\
\text { sebelum dan sesudah di } \\
\text { pakai }\end{array}$ \\
\hline 7 & $\begin{array}{l}\text { Perlengkapan } \\
\text { ibadah di } \\
\text { tempat } \\
\text { ibadah }\end{array}$ & $\begin{array}{l}\text { Perlengkapan } \\
\text { ibadah jarang } \\
\text { dibersihkan secara } \\
\text { berkala }\end{array}$ & $\begin{array}{l}\text { Virus dapat } \\
\text { menempel dan } \\
\text { menyebar pada } \\
\text { perlengkapan } \\
\text { ibadah tersebut }\end{array}$ & $\begin{array}{l}\text { Membawa } \\
\text { perlengkapan } \\
\text { ibadah sendiri } \\
\text { dan menjaga } \\
\text { jarak aman }\end{array}$ & $\begin{array}{l}\text { Selalu membersihkan } \\
\text { perlengkapan ibadah } \\
\text { secara berkala dan } \\
\text { menyemprotkan cairan } \\
\text { desinfectan pada benda } \\
\text { di tempat ibadah }\end{array}$ \\
\hline 8 & $\begin{array}{l}\text { Benda-benda } \\
\text { yang terdapat } \\
\text { pada ruang } \\
\text { guru }\end{array}$ & $\begin{array}{l}\text { Sering memegang } \\
\text { benda-benda } \\
\text { diruang guru, } \\
\text { sebagai contoh } \\
\text { meja, kursi, buku- } \\
\text { buku, alat tulis, } \\
\text { komputer, taplak } \\
\text { meja dan masih } \\
\text { banyak lagi }\end{array}$ & $\begin{array}{l}\text { Benda tersebut } \\
\text { dapat } \\
\text { menyebabkan virus } \\
\text { menempel dan } \\
\text { dapat menularkan } \\
\text { virus }\end{array}$ & 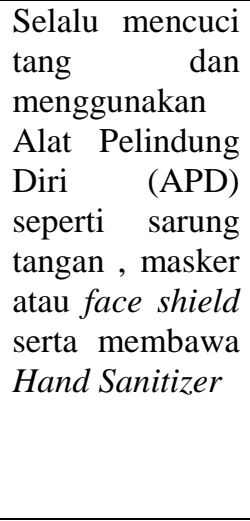 & \begin{tabular}{lr}
\multicolumn{3}{l}{ Menyemprotkan } \\
disinfektan pada benda- \\
benda di ruang guru, \\
rajin mencuci tangan \\
dengan & sabun \\
menggunakan & air \\
mengalir & atau \\
menggunakan & \\
handsanitizer & dan \\
menggunakan & APD \\
yang sesuai dengan \\
semestinya
\end{tabular} \\
\hline
\end{tabular}

\section{Kesimpulan dan Saran}

Kesimpulan yang dapat diambil dari penelitian ini berdasarkan rumusan masalah adalah sebagai berikut :

a. Terdapat potensi bahaya yang dapat terjadi akibat virus Covid-19 di lingkungan sekolah yang berasal dari sumber bahaya yang telah digolongkan menjadi 14 sumber kegiatan, terdapat? kegiatan yang dikategorikan risiko ekstrim dan? kegiatan yang dikategorikan dengan risisko tinggi

b. Risiko bahaya yang dapat ditimbulkan di lingkungan sekolah diantaranya risiko ekstrim dan ririsko tinggi, risiko tersebut dapat dikendalikan dengan penggunaan APD (Alat Pelindung Diri) dan eliminasi juga substitusi kegiatan

c. Rekomendasi yang dapat diberikan dalam penanganan virus Covid-19 di lingkungan sekolah, untuk menutup sementara sekolah hingga virus Covid-19 ini sudah mulai mereda, karena setelah diidentifikasi didapatkan banyak sekali potensi bahaya yang dapat menjadi media penularan virus Covid-19 di lingkungan sekolah.

Saran yang dapat diberikan antara lain, sebagai berikut : 
a. Melakukan pencegahan, penerapan dan pemeriksaan SOP untuk penanganan virus

b. Covid-19 dilingkungan sekolah dan mulai beradaptasi dengan "keadaan baru"

c. Menyediakan dan memfasilitasi peralatan APD oleh pihak sekolah

\section{Daftar Pustaka}

[1] S. Anand et al., "Prevalence of SARS-CoV-2 antibodies in a large nationwide sample of patients on dialysis in the USA: a cross-sectional study," Lancet, Oct. 2020.

[2] M. A. Shereen, S. Khan, A. Kazmi, N. Bashir, and R. Siddique, "COVID-19 infection: Origin, transmission, and characteristics of human coronaviruses," J. Adv. Res., vol. 24, pp. 91-98, 2020.

[3] T. M. Abd El-Aziz and J. D. Stockand, "Recent progress and challenges in drug development against COVID-19 coronavirus (SARS-CoV-2) - an update on the status," Infect. Genet. Evol., vol. 83, no. April, p. 104327, 2020.

[4] F. E. B. Setyawan and R. Lestari, "Challenges of Stay-At-Home Policy Implementation During the Coronavirus (Covid-19) Pandemic in Indonesia," J. Adm. Kesehat. Indones., vol. 8, no. 2, p. 15, 2020.

[5] A. R. A. H. Hamid, "Social responsibility of medical journal: A concern for covid-19 pandemic," Med. J. Indones., vol. 29, no. 1, pp. 1-3, 2020.

[6] Y.-C. Wu, C.-S. Chen, and Y.-J. Chan, "The outbreak of COVID-19: An overview," J. Chinese Med. Assoc., vol. 83, no. 3, 2020.

[7] D. K. Chu et al., "Physical distancing, face masks, and eye protection to prevent person-to-person transmission of SARS-CoV-2 and COVID-19: a systematic review and meta-analysis," Lancet, vol. 395, no. 10242, pp. 1973-1987, Jun. 2020.

[8] A. Sadikin and A. Hamidah, "Pembelajaran Daring di Tengah Wabah Covid-19," BIODIK, 2020.

[9] D. Jamaluddin, T. Ratnasih, H. Gunawan, and E. Paujiah, "Pembelajaran Daring Masa Pandemik Covid-19 Pada Calon Guru : Hambatan, Solusi dan Proyeksi," Karya Tulis Ilm. UIN Sunan Gunung Djjati Bandung, 2020.

[10] W. A. F. Dewi, "Dampak COVID-19 terhadap Implementasi Pembelajaran Daring di Sekolah Dasar," EDUKATIF J. ILMU Pendidik., 2020.

[11] S. R. B. Waode Azfari Azis, Laode Yusman Muriman, "ANALISIS FAKTOR RISIKO KECELAKAAN KERJA PADA PETANI PENYADAP POHON AREN ATAU ARENGA PINNATA MENGGUNAKAN METODE HAZARD IDENTIFICATION RISK ASSESSMENT AND RISK CONTROL Mhd.," $J$. Penelit. Perawat Prof., vol. 1, no. November, pp. 89-94, 2019.

[12] S. Rahayuningsih and J. A. Pradana, "Identifikasi Penerapan Dan Pemahaman Kesehatan Dan Keselamatan Kerja Dengan Metode Hazard And Operability Study (Hazop) Pada UMKM Eka Jaya," JATI UNIK J. Ilm. Tek. dan Manaj. Ind., vol. 2, no. 1, p. 20, 2019.

[13] W. Wijaya, S. Rahayuningsih, and A. Komari, "TINGKAT PERILAKU AMAN TENAGA KERJA BAGIAN JAHIT DENGAN MENGGUNAKAN METODE ANTECEDENT BEHAVIOR CONSEQUENCE DI PT. GLOW," JATI UNIK J. Ilm. 
Tek. dan Manaj. Ind., vol. 1, no. 1, pp. 34-43, 2019.

[14] T. Ihsan, B. V. Mayolan, S. M. Yardi, and T. Edwin, “Analisis penerapan recordable incident rate dalam sistem manajemen kesehatan dan keselamatan kerja di pt semen padang," J. Kesehat. Masy. Andala, pp. 3-9, 2019.

[15] D. S. Purnama, "Analisia Penerapan Metode Hirarc (Hazard Identification Risk Assessment and Risk Control) Dan Hazops (Hazard and Operability Study) Dalam Kegiatan Identifikasi Potensi Bahaya Dan Resiko Pada Proses Unloading Unit Di Pt. Toyota Astra Motor,” J. PASTI, vol. IX, no. 3, pp. 311-319, 2017.

[16] A. Primasari, H. Denny, and E. Ekawati, "Penerapan Hazard Identification Risk Assessment and Risk Control (Hirarc) Sebagai Pengendalian Potensi Kecelakaan Kerja Di Bagian Produksi Body Bus Pt. X Magelang," J. Kesehat. Masy., vol. 4, no. 1, pp. 284-292, 2016.

[17] R. Janius, K. Abdan, and Z. A. Zulkaflli, "Development of a disaster action plan for hospitals in Malaysia pertaining to critical engineering infrastructure risk analysis," Int. J. Disaster Risk Reduct., vol. 21, pp. 168-175, 2017.

[18] M. N. Bin Muhamad, R. Mohammad, N. Othman, and Z. A. Kadir, "Risk assessment of abrasive blasting environment in pressure vessel fabrication plants," J. Environ. Treat. Tech., vol. 8, no. 1, pp. 455-470, 2020.

[19] A. Y. Ambarani and A. R. Tualeka, "Hazard Identification and Risk Assessment (HIRA) Pada Proses Fabrikasi Plate Tanki 42-T-501A PT. Pertamina (Persero) RU VI Balongan,” Indones. J. Occup. Saf. Heal., vol. 5, no. 2, p. 192, 2017.

[20] A. Y. Tripariyanto, "Penerapan Metode HIRA dan Fishbone Diagram Pada Praktek Siswa SMK Yang Menimbulkan Risiko Kecelakaan Kerja Pada Bengkel Ototronik SMK, jurnal JATI UNIK, 2020, Vol.3, No.2,Hal :74-86,” vol. 3, no. 2, pp. 74-86, 2020.

[21] I. W. G. E. Triswandana and N. K. Armaeni, "Penilaian Risiko K3 Konstruksi Dengan Metode Hirarc," vol. 4, no. 1, pp. 2581-2157, 2020.

[22] A. Kurniawan, M. Santoso, and M. R. Dhani, "Identifikasi Bahaya pada Pekerjaan Maintenance Kapal Menggunakan Metode HIRARC dan FTA Dengan Pendekatan Fuzzy di Industri Kapal,” Kesehat. dan Keselam. Kerja, no. 2581, pp. 182-186, 2017.

[23] S. Syahrum., "Metodologi Penelitian Kuantitatif," KOMUNIKASI PENELITIAN KUANTITATIF Program Studi Jurnalistik \& Humas. 2014.

[24] Whidmurni, "Penelitian Kuantitatif," Pemaparan Metod. Kuantitatif, 2017. 